\title{
Variability in stratification and flushing times of the Gautami-Godavari estuary, India
}

\author{
B Sridevi ${ }^{1}, \mathrm{~V}$ V S S SARma ${ }^{1}, \mathrm{~T}$ V R Murty ${ }^{1, *}, \mathrm{Y} \mathrm{SAdHuram}^{1}$, N P C Redd ${ }^{1}$, \\ K ViJayakumaR ${ }^{2}$, N S N Raju ${ }^{1}$, CH JaWahar KumaR ${ }^{1}$, Y S N RaJu ${ }^{1}$, R Luis ${ }^{2}$, \\ M D KUMAR ${ }^{2}$ and K V S R PRASAD ${ }^{3}$ \\ ${ }^{1}$ CSIR - National Institute of Oceanography, Regional Centre, Visakhapatnam 530 017, India. \\ ${ }^{2}$ CSIR - National Institute of Oceanography, Dona Paula, Goa 403 004, India. \\ ${ }^{3}$ Department of Meteorology and Oceanography, Andhra University, Visakhapatnam 530 003, India. \\ *Corresponding author.e-mail: tvrmurty@nio.org
}

In order to examine the influence of forcing (river flow and tides) and anthropogenic activities (dredging and dam regulation) on stratification, a study was conducted over a period of 19 months (June 2008December 2009) in the Gautami-Godavari estuary (G-GE) during spring and neap tide periods covering entire spectrum of discharge over a distance of $36 \mathrm{~km}$ from the mouth. The bathymetry of the estuary was recently changed due to dredging of $\sim 20 \mathrm{~km}$ of the estuary from the mouth for transportation of barges. This significantly changed the mean depth and salinity of the estuary from its earlier state. The variations in the distribution of salinity in the Godavari estuary are driven by river discharge during wet period (June-November) and tides during dry period (December-May). The weak stratification was observed during high discharge (July-August) and no discharge (January-June) periods associated with dominant fresh water and marine water respectively. The strong stratification was developed associated with decrease in discharge during moderate discharge period (October-December). Relatively stronger stratification was noticed during neap than spring tides. The $15 \mathrm{psu}$ isohaline was observed to have migrated $\sim 2-3 \mathrm{~km}$ more towards upper estuary during spring than neap tide suggesting more salt enters during former than latter period. Total salt content was inversely correlated with river discharge and higher salt of about $400 \times 10^{6} \mathrm{~m}^{3}$ psu was observed during spring than neap tide. Flushing times varied between less than a day and more than a month during peak and no discharge periods respectively with lower times during spring than neap tide. The flushing times are controlled by river discharge during high discharge period, tides during dry period and both (river discharge and tides) under moderate discharge period. This study suggests that modification of discharge, either natural due to weak monsoon, or artificial such as dam constructions and re-routing the river flow, may have significant impact on the stratification and biogeochemistry of the Godavari estuary.

\section{Introduction}

An estuary is a semi-enclosed coastal body of water with a free connection to the open sea, within which the sea water is measurably diluted with freshwater derived from land drainage (Pritchard 1952; Cameron and Pritchard 1963). The vertical stratification of the estuary depends upon the volume of freshwater input and tides (Hansen and Rattray 1966). Jay and Smith (1990) reported that residual circulation changes with river flow, tides, storms and other low-frequency processes that play a significant role in salt estimation.

Keywords. Gautami-Godavari; stratification; spring-neap tides; freshwater fraction method; tidal prism. 
The Godavari estuary is the largest monsoonal estuary in India in terms of length and volume of discharge (Sarma et al. 2009). The river Godavari originates in the Western Ghats near Nasik city at an altitude of about $1620 \mathrm{~m}$ and flows eastwards through Godavari garben and joins the Bay of Bengal at Bhairavapalem (figure 1). The discharge of freshwater from the upstream is mainly controlled by Low Dam at Dowlaiswaram (Rao 1975; Sarma et al. 2009). After the dam, this estuary divides into two branches: the northward flowing Gautami-Godavari (G-GE), and the southward flowing Vasistha-Godavari (V-GE). Since the major discharge occurs through G-GE compared to $\mathrm{V}-\mathrm{GE}$, most of the earlier studies were carried out in the former branch. This estuary is influenced by Indian Summer Monsoon (ISM; (JuneSeptember)). Recently, Vijith et al. (2009) found unsteady state in the monsoonal estuaries due to special characteristic of monsoonal runoff. The runoff into monsoonal estuaries is highly seasonal and exceeds the total volume of the estuary during peak discharge period (Vijith et al. 2009). Therefore, stratification in the estuary is controlled by river flow during ISM, and horizontal diffusion of salt due to tides during dry period.

Ranga Rao et al. (1988) studied G-GE from mouth to $\sim 22 \mathrm{~km}$ upstream at monthly intervals (except during March and August) and observed that salinity in the estuary was mainly controlled by discharge during ISM with strong stratification whereas well mixed conditions were found during January. However, they did not collect data during peak discharge period (i.e., August) to examine the stratification in the estuary. Reddy and Ranga Rao (1993) estimated flushing time in G-GE during September (48 h) and December (552 h) and no efforts were made during other periods, especially during peak discharge and no discharge periods. Jyothi et al. (2000) measured salinity in the estuary during January, April and November in G-GE and observed increase in salt content by $62 \%$ and $32 \%$ from November to January and from January to April, respectively. Narasimha Rao (2001) observed that stratification was stronger at low water slacks and weaker at high water slacks. Recently, Shetye et al. (2007) noticed weak salinity stratification during spring ( $\sim 2$ psu of salinity difference between surface and bottom) than neap tide ( $\sim 6 \mathrm{psu})$ in the Mandovi estuary. Therefore, the magnitude of tidal range has significant impact on strength of mixing and stratification in the estuary.

The studies carried out so far in the G-GE have not covered entire river discharge spectrum, impact of spring and neap tides on stratification, salt intrusion to the upstream estuary and flushing

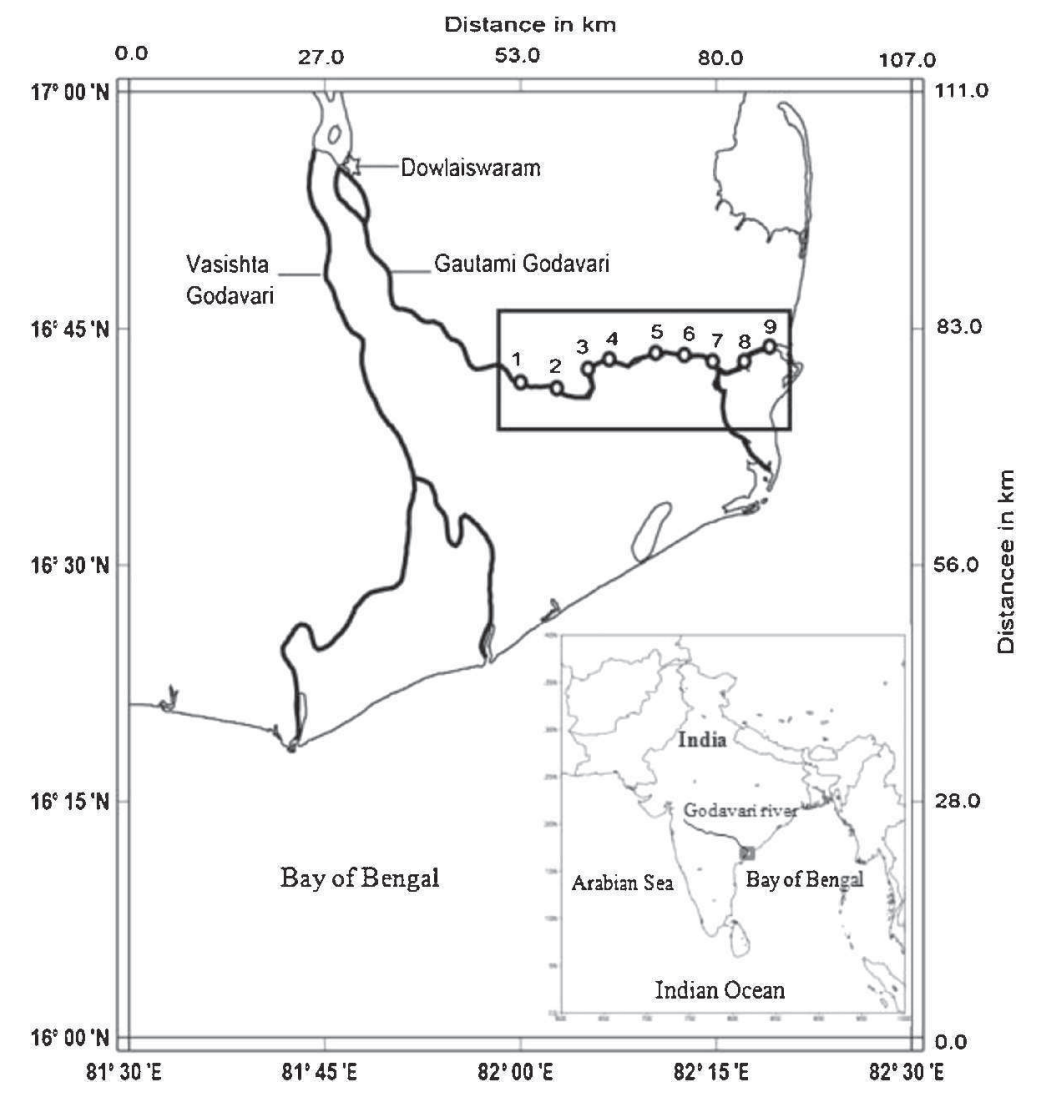

Figure 1. Study area along with the station locations (1-9). 
time. In addition to this, earlier studies carried out about two decades ago and recent changes, such as bathymetry and monsoonal intensity, might have modified physical processes in the $\mathrm{G}-\mathrm{GE}$. In order to examine these, a systematic study extending over 19 months, was carried out to understand the influence of river discharge and tides on stratification, intrusion of salt, salt budget and flushing time in the G-GE. The data collection and methodology adopted is explained in section 2, while results are given in section 3 . Finally, the conclusions and the intra and inter-annual variability in river discharge, variations in stratification, salt intrusion and flushing times of the estuary with reference to recent variability in bathymetry and tides are discussed in section 4.

\section{Data and methodology}

\subsection{Study area}

Godavari estuary is characterized by many islands and creeks that significantly influence flow of water (Narasimha Rao 2001). The tides in the estuary are semi-diurnal with spring and neap tides in the ranges of $1.0-1.5$ and $0.27-0.7 \mathrm{~m}$, respectively. The average depth and width of the estuary is 8 and $1200 \mathrm{~m}$, respectively, which were $\sim 12$ and $1000 \mathrm{~m}$ during 1990 (Reddy and Ranga Rao 1993).

Coarse sand from the upstream river (Kotipalli) is being dredged for domestic purposes, as it is widely used in the civil engineering sector. This led to increase in depth from $6 \mathrm{~m}$ during 1990 (Ranga Rao et al. 1988) to $11 \mathrm{~m}$ during study period. On the other hand, dredging was carried out from mouth to middle of the estuary (up to station 6, Yanam) (figure 2a) in 2007 for transportation of barges. Such activities led to increase in the depth of mid-estuary in recent years to $21 \mathrm{~m}$ from that of earlier $(\sim 10 \mathrm{~m})$. At the mouth, the estuary was widened and shallowed $(7 \mathrm{~m})$ compared to that two decades earlier. The width to depth ratio increased from mouth to upstream during 1990, whereas it decreased during 2008 due to dredging (Sridevi 2013). Since the estuarine bathymetry changed during last 20 years due to anthropogenic activities, it is hypothesized that stratification of the estuary might have been modified in the recent years.

\subsection{Data}

Bathymetry data of the estuary was collected during June 2008 from mouth to upstream, over a stretch of $36 \mathrm{~km}$, at $500 \times 50 \mathrm{~m}$ grid spacing using Differential Global Positioning System (DGPS; Ceeducer, Australia). The DGPS is a satellite-based
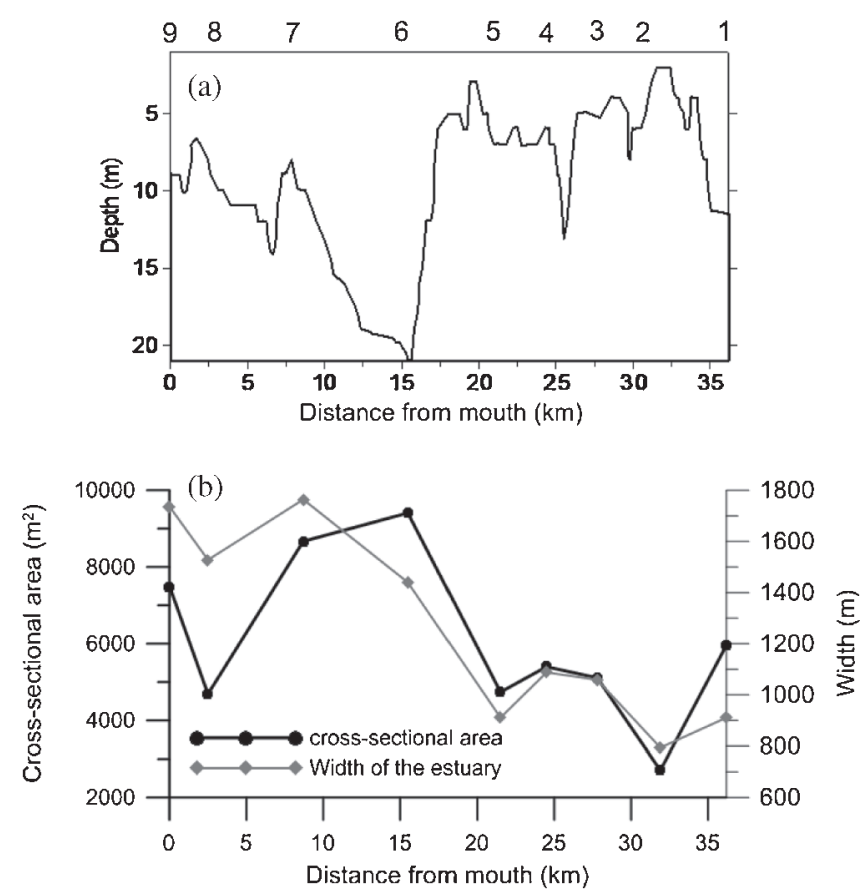

Figure 2. Variability of (a) along channel depth and (b) cross-sectional area at transect locations in the GautamiGodavari estuary. The numbers on the top indicate station numbers. The distance was calculated from the mouth of the estuary (Bhairavapalem) to the upstream.

navigation surveying system with the accuracy of $\pm 1 \mathrm{~m}$ and $1 \mathrm{~cm}$ for geographical position and depth values respectively. The depth measurements were made by transmitting the acoustic pulse at $200 \mathrm{kHz}$ frequency through the water media. The received acoustic pulse was processed with the principle of sound velocity in the water and the processed output was digitally recorded as depth value. The crosssectional area at each station was computed using spline interpolation technique (Ralston and Wilf 1966). The cross-sectional area increased from mouth to $16 \mathrm{~km}$ towards the head of the estuary except at station 8 (figure $2 \mathrm{~b}$ ). Further upstream of station 6 , it decreased until station 2 and then again increased at station 1 (head of the estuary) (figure $2 \mathrm{~b}$ ).

Vertical profiles of temperature and salinity were collected at 9 stations from June 2008 to December 2009 during spring and neap tide periods along the channel using conductivity, temperature and depth profiler (CTD; SBE19 plus Seacat profiler, Sea Bird Electronics, USA). The accuracy of temperature and conductivity were $0.005^{\circ} \mathrm{C}$ and 0.0005 , respectively, and salinity was obtained from conductivity. A mechanized boat was used to cover about $36 \mathrm{~km}$ upstream from the mouth.

Daily river discharge data was obtained from dam authorities at Dowlaiswaram (figure 1). Water elevation was measured at an interval of $10 \mathrm{~min}$ by a tide gauge, designed by Marine Instrument Division, National Institute of Oceanography, Goa, 
installed at station 6. Stratification was estimated as the difference between salinity at surface and bottom, following Haas (1977).

\subsection{Total salt content}

The total salt content of the estuary was computed by considering salinity $(S)$ as a continuous function of distance $(\mathrm{km})$ from mouth to upstream. Then $S_{\text {tot }}$ is given by the following equation (Jyothi et al. 2000:

$$
S_{\mathrm{tot}}=\int_{0}^{L} S(x) A(x) d x
$$

where $A(x)$ is the cross-sectional area of the estuary at $x$. The upper limit $L$ denotes length of the estuary and it is $36 \mathrm{~km}$ for the present study. Salt content between two successive stations was computed by a cubic spline integration method (Ralston and Wilf 1966) using salinity and crosssectional area; the salt content was integrated along the length of the entire estuary to get total salt content.

\subsection{Computation of flushing time (T)}

Flushing time $(T)$ can be defined as the average time taken by a parcel of freshwater to pass through the estuary (Bowden 1980) or the time required to renew existing volume of water in an estuary (Monsen et al. 2002). This $T$ can be estimated following two methods, namely, freshwater fraction method (Dyer 1973; Huang 2007) and tidal prism method (Monsen et al. 2002).

\subsubsection{Freshwater fraction method}

The fraction of the freshwater $(f)$ at a particular location is given by:

$$
f=\frac{\left(S_{0}-S\right)}{S_{0}},
$$

where $S_{0}$ represents mean oceanic salinity. For the present case, $S_{0}$ is taken as mean observed salinity of 33 psu. $S$ is the depth averaged salinity at a particular location. Flushing time given by freshwater fraction method is:

$$
T=\frac{F}{Q}=\frac{\int_{\mathrm{Vol}}^{f d(V)}}{Q},
$$

where $F$ is the volume of the freshwater present in the estuary and $Q$ is the rate of river discharge. $V$ is the volume of the estuary. This method accounts for the influence of river discharge, salinity intrusion and gravitational circulation (Sheldon and Alber 2006). This method, however, is not valid during negligible or no discharge period.

\subsubsection{Tidal prism method}

Tides dominate the estuarine circulation during no discharge period (Monsen et al. 2002) and hence flushing times were estimated using tidal prism method when discharge was negligible. Flushing time given by tidal prism method is:

$$
T=\frac{V T_{\text {tidal }}}{(1-b) P}
$$

where $T_{\text {tidal }}$ is tidal period, $b$ is return flow factor and $P$ is the tidal prism (Monsen et al. 2002). Based on the high resolution shallow seismic survey, the volume of the estuary was precisely computed as $2.77 \times 10^{8} \mathrm{~m}^{3}$ (volume between upstream and mouth). Semi-diurnal period $\left(T_{\text {tidal }}\right)$ is predominant in the Godavari estuary (0.53 days; $12.42 \mathrm{~h}$ ). $P$ is the tidal prism in $\mathrm{m}^{3}$ and it is approximately the product of surface area of the estuary and tidal range. Vijith et al. (2009) considered $b$ as 0.5 in the Mandovi estuary. It means that about $50 \%$ of the water that goes out of the estuary during ebb tide returns to the estuary during consecutive flood tide. Hence, the flushing time derived from the tidal prism method may be either under- or over-estimated according to Luketina (1998). Tidal prism method was adopted for zero and low discharge (i.e., on 8 June and 26 October 2009) periods.

\section{Results}

\subsection{Intra- and inter-annual variations in river discharge}

The rate of daily river discharge in the Godavari estuary varied from 0 to $11015 \mathrm{~m}^{3} \mathrm{~s}^{-1}$ during 2008 . The onset of monsoon occurs during June, but the peak in river discharge was observed during July $\left(3216 \mathrm{~m}^{3} \mathrm{~s}^{-1}\right)$. The discharge decreased by the end of August 2008 and peaked again during the first week of September and decreased rapidly from October to December to the negligible rates with the withdrawal of the ISM.

In contrast, pulsed nature of discharge was observed during 2009 due to breaks in monsoonal rainfall. Significant discharge was observed during July and virtually stopped by the middle of August for about 2 weeks and then increased sharply by the end of August. By the end of September, discharge decreased to minimum and stopped completely by December. The total annual river runoff in $2008\left(180 \mathrm{~m}^{3} \mathrm{~d}^{-1}\right)$ was more than double to that of $2009\left(68 \mathrm{~m}^{3} \mathrm{~d}^{-1}\right)$. Peak discharge was more than three times higher during $2008\left(>11000 \mathrm{~m}^{3} \mathrm{~s}^{-1}\right)$ than $2009\left(\sim 3000 \mathrm{~m}^{3} \mathrm{~s}^{-1}\right)$. The number of days and daily discharge exceeded the volume of the estuary $\left(2.77 \times 10^{8} \mathrm{~m}^{3}\right)$. It was $25(\sim 6 \times 4)$ in 2008 and was 
only 4 in 2009 . As a result, the estuary was flushed $\sim 6$ times more during 2008 than 2009 .

\subsection{Spatial and temporal variability in stratification}

\subsubsection{Influence of river flow}

The discharge initiated the development of stratification and disappeared with insignificant horizontal and vertical variations in salinity, when river flow is greater than or equal to the volume of the estuary. For instance, the volume of freshwater discharge recorded at the head of the estuary on 19 August, $2008\left(2.58 \times 10^{8} \mathrm{~m}^{3}\right.$ day $\left.^{-1}\right)$ (figure $3 \mathrm{~d}$ ) was just about the volume of the estuary $\left(>2.77 \times 10^{8} \mathrm{~m}^{3}\right)$ that led to filling of the entire estuary with freshwater, with no stratification (figure 4b). Saline water intrudes into the estuary with the decrease of discharge $\left(87 \times 10^{6} \mathrm{~m}^{3}\right.$ day $^{-1}$; figure $\left.4 \mathrm{c}\right)$ and a horizontal as well as vertical salinity gradient develops. Due to intrusion of saline water at the bottom, high vertical salinity difference was noticed in the middle (6 psu) and lower estuaries (5 psu) in October (figure 4c). During this time, the orientation of isohalines indicated the turning of the estuary from a salt wedge to a partially mixed type estuary (figure 4c). On further decrease of discharge, estuary turned from a partially mixed type to a well mixed type (figure 4d) and this resulted in low vertical salinity difference (figure $4 \mathrm{~d}$ ) due to dominance of salt water in the entire estuary and termination of freshwater input from upstream end.

Discharge also influenced the amount of salt present in the estuary. For instance, the intrusion of saline water, represented as the distance between the mouth and location of 2 psu isohaline, into estuary was up to $\sim 24 \mathrm{~km}$ (station 4 ) from the mouth on 31st October 2008 when the discharge was $100 \mathrm{~m}^{3} \mathrm{~s}^{-1}$ (figure 4c). On the other hand, 2 psu isohaline was noticed beyond $36 \mathrm{~km}$ (study region) from the mouth during no discharge period with weak salinity gradient between surface and bottom suggesting estuary is of well-mixed type (figure 4d).

The salinity difference between surface and bottom was variable along the estuary due to changes in bathymetric structure. For example, the vertical salinity difference was higher (15 psu) on 20 June 2008 at station 6 , where the water column was the deepest $(21 \mathrm{~m})$, and this difference was $\sim 2$ and 0 psu at the mouth of the estuary where depth of the water column was $\sim 6 \mathrm{~m}$ and at the upstream where the water column depth was $\sim 11 \mathrm{~m}$ (figure $4 \mathrm{a}$ ). The orientation of isohalines clearly indicates that salinity distribution in the middle of the estuary was sandwiched between tidal effect from mouth and discharge from the upstream.

\subsubsection{Influence of tides}

Semi-diurnal tides were predominant with a tidal range of $1.0-1.5 \mathrm{~m}$ during spring and $0.3-0.7 \mathrm{~m}$ during neap tide (table 1 ). Tides played a significant role in penetration of salt into the estuary during moderate and negligible discharge periods. For example, $33 \mathrm{psu}$ of salinity was noticed at the mouth of the estuary during 8 June 2009 (spring tide) and it was 30 psu during 16 June 2009 (neap tide) (figure $5 \mathrm{~d}$ ) at the same location. The difference of 3 psu salinity between spring and neap tides suggests that more salt water intruded into the estuary during the former than the latter period. On the other hand, the difference in salinity at the mouth/head of the estuary was less $(\sim 1 \mathrm{psu})$ during negligible discharge period when the tide changed from spring to neap (figure $5 \mathrm{a}$ and b). During October 2009, the decrease of discharge from 252 to $2 \mathrm{~m}^{3} \mathrm{~s}^{-1}$ (table 1 ) from spring to neap tide, resulted in higher salinities at the bottom during the neap tide (17 psu) than the spring tide (13 psu) in the middle of the estuary (figure $5 \mathrm{~g}$ and $\mathrm{h}$ ). So, it is difficult to capture the difference in salinity between spring and neap tides during discharge period as freshwater discharge dominates on salinity variations over the tidal effect. For instance, high salinity intrusion was noticed during neap tide on 27 August 2008 compared to spring tide (19 August 2008) when the river discharge was 2989.9 and $1474.7 \mathrm{~m}^{3} \mathrm{~s}^{-1}$ respectively, suggesting that magnitude of discharge dominates more than tides on salt intrusion (figure 5e and $\mathrm{f}$ ).

In order to examine the monthly variability in salinity stratification during spring and neap tide at upper (station 1; figure 3a), middle (station 6; figure $3 \mathrm{~b}$ ) and lower estuary (station 9; figure 3c), the salinity difference between surface and bottom was plotted with reference to discharge in figure 3 . From this figure, it is observed that the variability in stratification was noticed from August 2008 to June 2009 between spring and neap tide and it was higher during the former period than in the latter period. Furthermore, the highest stratification was noticed at station 6 (middle estuary) in the entire estuary due to deep water column. In order to further examine the variations in salinity intrusion during spring and neap tides, the location of 15 psu isohaline from the mouth of the estuary was examined during the period of observation (figure $3 \mathrm{~d})$. The $15 \mathrm{psu}$ isoline was observed relatively more towards upstream by $2-3 \mathrm{~km}$ during spring than neap tide in dry period. Before the onset of ISM (during April 2009), 15 psu isohaline reached up to $36 \mathrm{~km}$ from the mouth and it decreased to $\sim 18 \mathrm{~km}$ during moderate discharge $\left(120 \mathrm{~m}^{3} \mathrm{~s}^{-1}\right)$ and disappeared during August to October (figure $3 \mathrm{~d})$. The $15 \mathrm{psu}$ isohaline appeared at $6 \mathrm{~km}$ from 

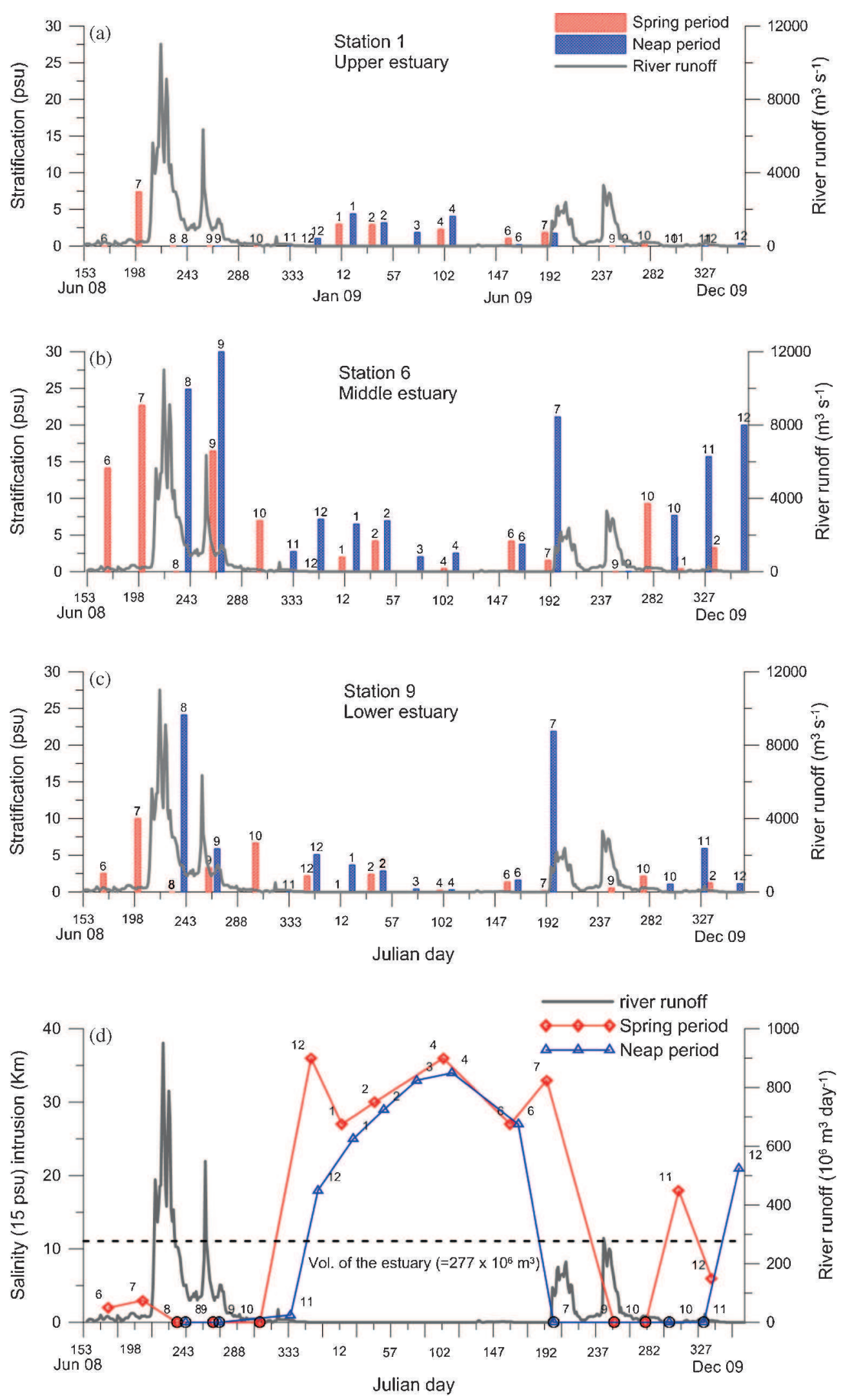

Figure 3. Vertical spring-neap stratification of (a) upper (station 1), (b) middle (station 6), (c) lower (station 9) estuary and (d) intrusion of 15 psu salinity contour during spring and neap tides in the Godavari estuary on the left axis and river discharge on the right axis during the observational period. [Stratification was estimated as the difference between the top and bottom layer salinity; numbers on the top of each bar indicate the month in a year.] 

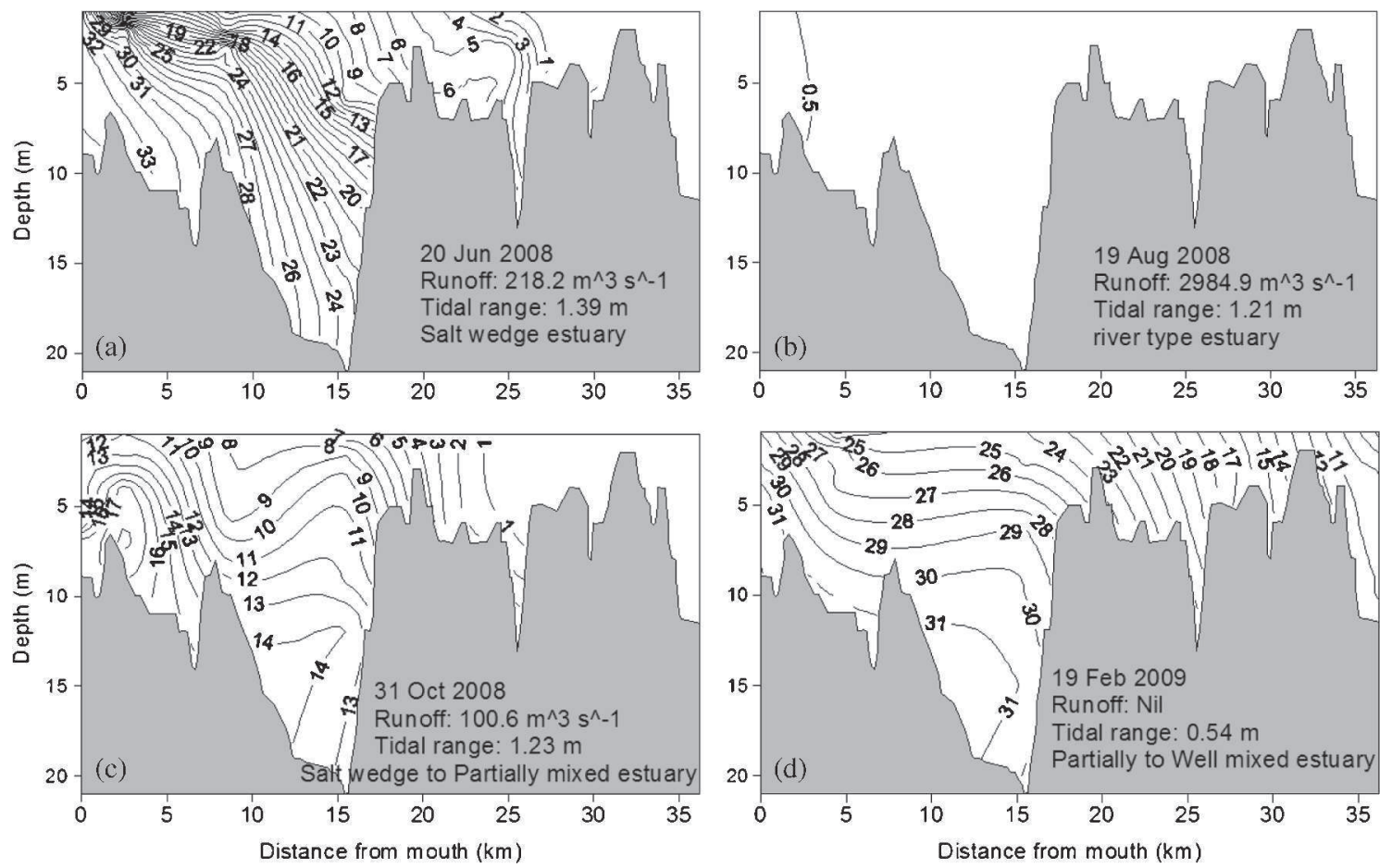

Figure 4. Along-channel sections of salinity in the Godavari estuary during (a) 20 June, 2008, (b) 19 August, 2008, (c) 31 October, 2008 and (d) 19 February, 2009.

Table 1. Distribution of total salt content and flushing times of the Gautami-Godavari estuary.

\begin{tabular}{|c|c|c|c|c|c|c|}
\hline Sl. no. & Date & $\begin{array}{l}\text { Tidal range } \\
\qquad(\mathrm{m})\end{array}$ & $\begin{array}{l}\text { River discharge } \\
\qquad\left(\mathrm{m}^{3} \mathrm{~s}^{-1}\right)\end{array}$ & $\begin{array}{l}\text { Freshwater volume } \\
\qquad\left(10^{6} \mathrm{~m}^{3}\right)\end{array}$ & $\begin{array}{l}\text { Total salt content } \\
\qquad\left(10^{6} \mathrm{~m}^{3} \mathrm{psu}\right)\end{array}$ & $\begin{array}{l}\text { Flushing } \\
\text { time (days) }\end{array}$ \\
\hline 1 & 20 Jun 2008 (S) & $1.39^{* *}$ & 218.2 & 144.0 & 2410.2 & 7.63 \\
\hline 2 & $20 \mathrm{Jul} 2008$ (S) & $1.30^{*}$ & 244.3 & 155.6 & 2005.3 & 7.37 \\
\hline 3 & 19 Aug 2008 (S) & $1.21^{* *}$ & 2984.9 & 212.1 & 25.4 & 0.82 \\
\hline 4 & 27 Aug $2008(\mathrm{~N})$ & $0.57^{* *}$ & 1474.7 & 202.4 & 364.4 & 1.59 \\
\hline 5 & 20 Sep $2008(\mathrm{~S})$ & $1.24^{*}$ & 1001.1 & 208.9 & 136.0 & 2.42 \\
\hline 6 & 25 Sep $2008(N)$ & $0.72^{* *}$ & 1232.6 & 188.6 & 849.7 & 1.77 \\
\hline 7 & 31 Oct $2008(\mathrm{~S})$ & $1.23^{*}$ & 100.6 & 173.3 & 1383.1 & 19.94 \\
\hline 8 & 27 Nov $2008(\mathrm{~N})$ & $0.98^{* *}$ & 90.9 & 189.2 & 685.7 & 24.01 \\
\hline 9 & 15 Dec $2008(\mathrm{~S})$ & $1.21^{* *}$ & 0.0 & 121.1 & 3214.9 & $8.6 \pm 4.6$ \\
\hline 10 & $21 \operatorname{Dec} 2008(\mathrm{~N})$ & $0.74^{*}$ & 0.0 & 131.4 & 2853.2 & $14.1 \pm 7.6$ \\
\hline 11 & 11 Jan $2009(\mathrm{~S})$ & $1.31^{* *}$ & 0.0 & 104.9 & 3781.9 & $8.0 \pm 4.3$ \\
\hline 12 & $21 \operatorname{Jan} 2009(\mathrm{~N})$ & $0.69^{*}$ & 0.0 & 114.9 & 3429.6 & $15.1 \pm 8.2$ \\
\hline 13 & 09 Feb $2009(\mathrm{~S})$ & $1.03^{* *}$ & 0.0 & 87.8 & 4379.6 & $10.1 \pm 5.5$ \\
\hline 14 & 19 Feb $2009(\mathrm{~N})$ & $0.54^{* *}$ & 0.0 & 89.3 & 4327.5 & $19.3 \pm 10.6$ \\
\hline 15 & 18 Mar $2009(\mathrm{~N})$ & $0.53^{* *}$ & 0.0 & 75.3 & 4819.1 & $19.7 \pm 10.7$ \\
\hline 16 & 10 Apr $2009(\mathrm{~S})$ & $1.34^{* *}$ & 0.0 & 58.4 & 5408.6 & $7.8 \pm 4.2$ \\
\hline 17 & 18 Apr $2009(\mathrm{~N})$ & $0.41^{*}$ & 0.0 & 69.0 & 5039.1 & $25.4 \pm 13.8$ \\
\hline 18 & 08 Jun 2009 (S) & $1.10^{* *}$ & 20.2 & 155.6 & 2005.3 & $9.5 \pm 5.1$ \\
\hline 19 & 16 Jun $2009(\mathrm{~N})$ & $0.70^{*}$ & 0.0 & 96.0 & 4309.4 & $14.9 \pm 8.1$ \\
\hline 20 & 10 Jul 2009 (S) & $1.19^{* *}$ & 0.0 & 69.8 & 5010.8 & $8.8 \pm 4.7$ \\
\hline 21 & 16 Jul $2009(\mathrm{~N})$ & $0.57^{*}$ & 1288.8 & 170.7 & 1476.2 & 1.53 \\
\hline 22 & 07 Sep $2009(\mathrm{~S})$ & $1.35^{* *}$ & 1717.5 & 212.3 & 17.6 & 1.43 \\
\hline 23 & 05 Oct $2009(\mathrm{~S})$ & $1.32^{* *}$ & 251.9 & 184.9 & 981.3 & 8.49 \\
\hline 24 & 26 Oct $2009(\mathrm{~N})$ & $0.27^{*}$ & 2.3 & 165.6 & 1655.9 & $38.6 \pm 20.9$ \\
\hline 25 & 25 Nov $2009(\mathrm{~N})$ & $0.50^{*}$ & 120.3 & 188.6 & 849.6 & 18.14 \\
\hline 26 & 02 Dec $2009(\mathrm{~S})$ & $1.28^{* *}$ & 79.3 & 163.8 & 1715.5 & 24.0 \\
\hline 27 & 26 Dec $2009(\mathrm{~N})$ & $0.81^{*}$ & 0.0 & 128.3 & 2959.0 & $12.9 \pm 7.0$ \\
\hline
\end{tabular}

Note. S: Spring; N: Neap period; $* *$ : ebb and $*$ : flood tide. 
the mouth during December 2009 during spring tide, whereas it was found at $21 \mathrm{~km}$ during neap tide (figure 3d) due to discharge of freshwater (79.3 $\left.\mathrm{m}^{3} \mathrm{~s}^{-1}\right)$ during the former period.

\subsection{Flushing times and salt budget}

With the onset of ISM, the total salt content of the whole estuary decreased during wet period and increased during dry period. The lowest salt content $\left(25 \times 10^{6} \mathrm{~m}^{3} \mathrm{psu}\right)$ was noticed in the estuary during peak discharge period (19 August, 2008) which is $<0.5 \%$ of the salt content estimated during dry period $\left(5409 \times 10^{6} \mathrm{~m}^{3}\right.$ psu on 10 April, 2009). The total salt content increased with the decrease in the discharge and displayed strong inverse correlation $\left(r^{2}=0.64 ; n=27 ; p<0.001\right.$ ) (figure 6 ). It was further noticed that $\sim 400 \times 10^{6} \mathrm{~m}^{3} \mathrm{psu}$ more salt was added to the estuary during spring than neap tide in dry period.
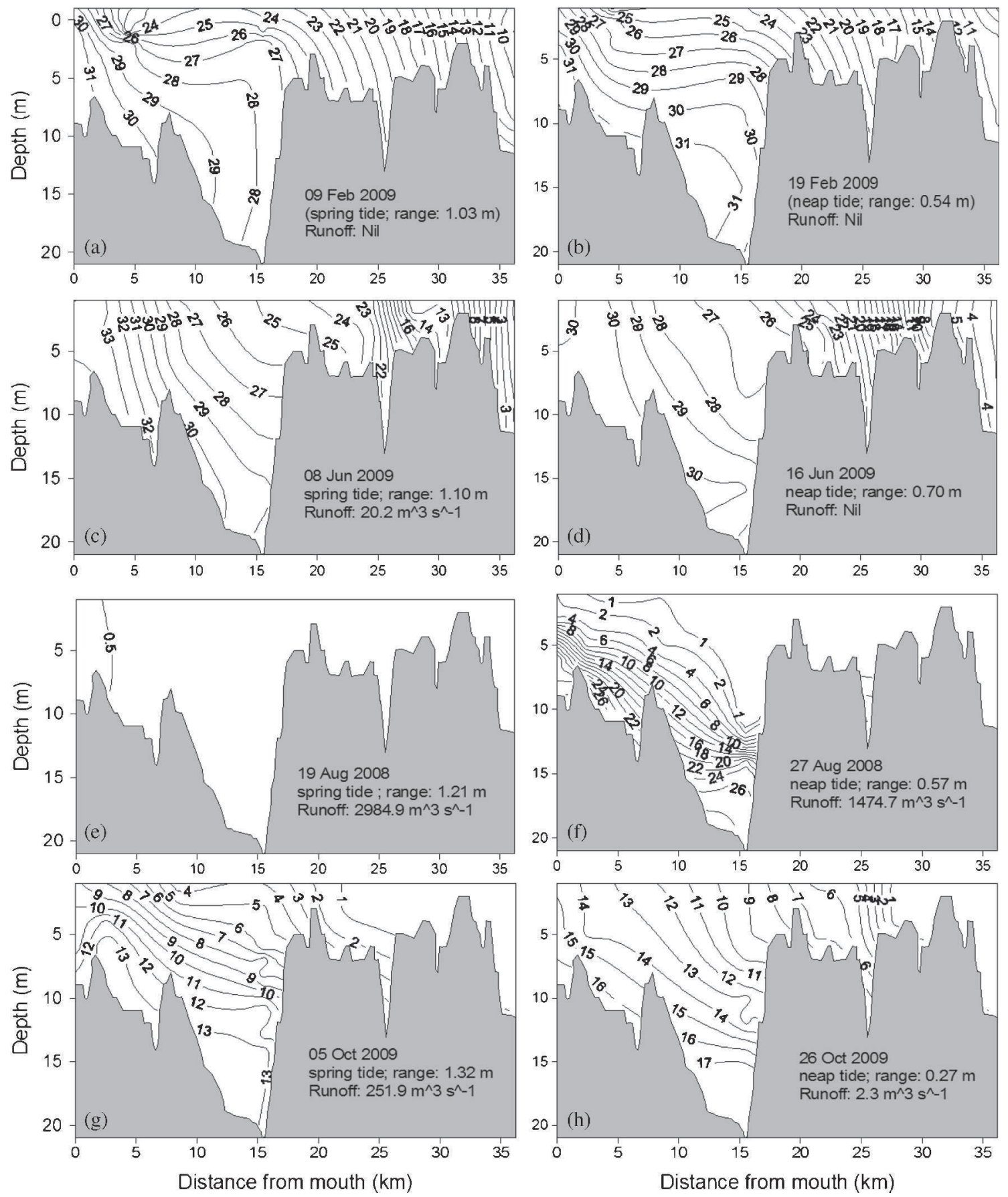

Figure 5. Along-channel sections of salinity in the Godavari estuary during spring tide (a, $\mathbf{c}, \mathbf{e}$ and $\mathbf{g})$ and neap tide (b, d, f and $\mathbf{h}$ ) during February, June, August and October. 


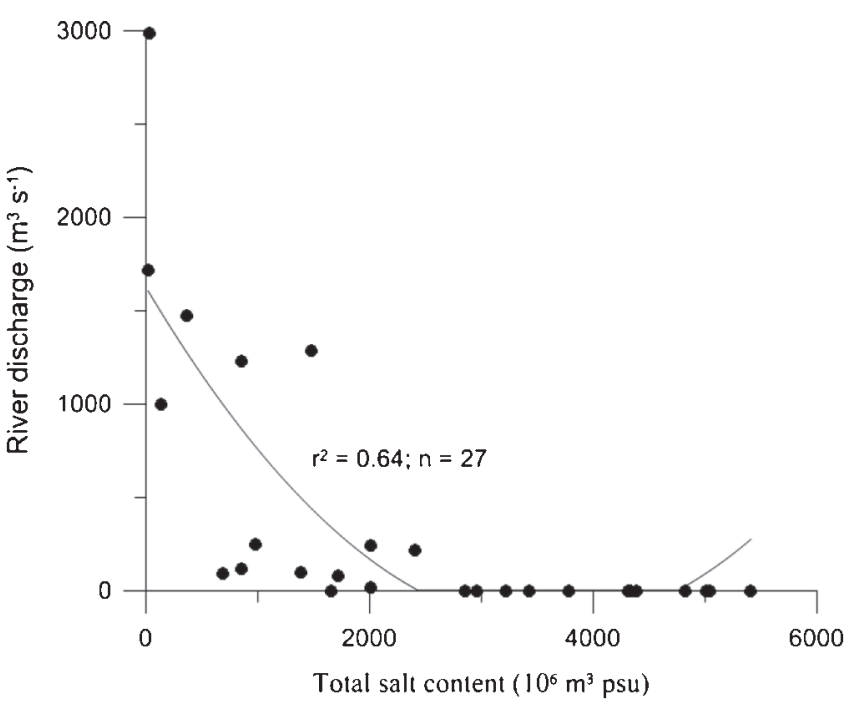

Figure 6. Correlation between river discharge and salt content in the Godavari estuary during the observation period.

Flushing times varied from less than a day to more than a month. To examine possible variations in flushing time through tidal prism method, it was computed at variable $b$ values ranging from 0.2 to 0.8 and results are presented with mean and standard deviation in table 1 . During peak discharge period (19 August, 2008), less than a day was sufficient to completely replace the water in the estuary with freshwater. Due to high discharge rates, the estuary was flushed several times more in 2008 than in 2009. With the decrease of discharge rates, flushing times increased and reached to more than a month $(38.6 \pm 20.9$ days; for $b$ is 0.2 to 0.8$)$ at the lowest tidal range of $0.27 \mathrm{~m}$ (26 October, 2009; table 1). Relatively higher flushing rates, higher by $\sim 6$ days, were estimated during neap tide than spring tide.

\section{Summary and discussion}

The source of freshwater in the Godavari river is monsoonal precipitation over the Indian subcontinent during ISM. Therefore, the magnitude of discharge to the Godavari estuary is dependent on the intensity of ISM (Acharyya et al. 2012). In addition to this, several dams constructed over the Godavari river also control the freshwater discharge. Water is released from the dam, whenever the volume of water in the dam exceeds its capacity. Therefore, the river discharge into the estuary was rather controlled by not only precipitation but also by the dam authorities. The total annual discharge and peak discharge days in 2009 were much smaller than that in 2008 due to weaker monsoon over Indian subcontinent (www.imd.gov. in/doc/warm2009.pdf) during former than latter (Preethi et al. 2011). The intra- and inter-annual variations in river discharge have significant impact on stratification of the estuary (figure 3 ).

Stratification slowly developed in July due to initiation of discharge. When the discharge reached its peak, it exceeded volume of the estuary $\left(>2.77 \times 10^{8}\right.$ $\mathrm{m}^{3}$ ) and the entire estuary was filled with freshwater and turned into a river with no vertical and horizontal salinity gradient. Such conditions usually occurred in August. Though peak ISM occurs in July in the west coast, there will be a time lag of about one month for peak discharge in the east coast rivers as it needs to fill the entire basin before it discharges to the estuary. Once the monsoon withdrew, discharge decreased $\left(<1.73 \times 10^{8}\right.$ $\left.\mathrm{m}^{3} \mathrm{~d}^{-1}\right)$ and stratification developed both horizontally and vertically. During this period, the estuary turned to a partially mixed type and then gradually to a well mixed estuary during dry period (January-May) (figure 4) associated with termination of discharge. The asymmetry in salinity was noticed between the spring and neap tides (figures 3 and 5). The spatial and temporal variations in the stratification of the estuary were influenced by river discharge and tides during wet period, whereas tides alone governed during dry period.

The magnitude of the mixing and strength of the stratification during discharge or non-discharge conditions is determined by rate of change of water level, which varies for flood/ebb or spring/neap tide periods. During peak discharge period, springneap stratification variability was overwhelmed by variability in discharge. With the onset and withdrawal of the monsoon, stratification developed in the estuary with low saline water at the upper level and saline water at the bottom. High variability in stratification from spring to neap tide was observed in middle estuary where deep water column led to trapping of high saline water at the bottom. The salt water intruded up to $2-3 \mathrm{~km}$ more towards upper estuary during spring tide compared to neap tide during dry period due to high tidal amplitude during former than latter. The difference of mean salinities between spring and neap tides was $\sim 2$ psu up to $15 \mathrm{~km}$ from the mouth, then increased to $\sim 5 \mathrm{psu}$ between 15 and $30 \mathrm{~km}$ and decreased to $2 \mathrm{psu}$ further upstream $(>30 \mathrm{~km})$. Shetye et al. (2007) reported that $\sim 2$ and 6 psu of vertical salinity difference was noticed during February in the Mandovi estuary. The position of 15 psu contour depended more on the discharge than tide during discharge period. After the withdrawal of monsoon, stratification increased (figure 4) and 15 psu isohaline intruded further upstream. The spring to neap salinity variability was large in the middle to upstream of the estuary, whereas it was similar to that of variations observed between ebb and flood tide at the mouth of the estuary (Acharyya 2012). 
On an average, the estuary was saltier by $\sim 9 \%$ during spring than that of neap tide during entire study period (table 1). As the discharge began, the total salt in the estuary decreased during first week of June 2009, while salt content almost doubled in the second week as the discharge decreased to almost zero. In addition to tides, the lulls and peaks in the discharge influenced the total salt content in the estuary. It has been observed that $\sim 15 \%$ of more salt was noticed in April 2009 compared to April 1996 (Jyothi et al. 2000) and this decrease can be attributed to some amount of discharge that occurred during the latter period $(\sim 20$ $\mathrm{m}^{3} \mathrm{~s}^{-1}$ ), while it was negligible during the former period.

Significant modification in bathymetry during recent years due to dredging activities in the estuary (section 2.2; figure $2 \mathrm{~b}$ ) increased salt intrusion to upstream estuary. In order to examine the recent changes, we had compared the salinity data collected during no discharge period of February 1987 (Ranga Rao 1991) with the data collected during February 2009 (figure 5a and b). It was noticed that salinity at the middle estuary region (station no. 6 in the present study) was 24 and 20 psu during high and low tides, respectively during February 1987 (Ranga Rao 1991) and the same was increased to 28 and $27 \mathrm{psu}$, respectively during ebb period of spring and neap tides in February 2009 (figure $5 \mathrm{a}$ and $\mathrm{b}$ ). This suggests that recent change in bathymetry has resulted in an increase in salt content of the estuary and upstream region has become more salty during recent years. Reddy and Ranga Rao (1993) estimated a flushing time of $\sim 25$ days during December when the average monthly discharge was $40 \mathrm{~m}^{3} \mathrm{~s}^{-1}$, while it was $\sim 16$ days when monthly average discharge was $18 \mathrm{~m}^{3} \mathrm{~s}^{-1}$ during December 2009. Even though monthly discharge during December 2009 was less than earlier, lower flushing times during former period suggest the intrusion of more saline water during recent years due to dredging of the estuary.

In summary, this study suggests that intraannual variations in the salinity of the estuary were related to monsoonal precipitation pattern in the watershed. Strong stratification was observed in the estuary associating with initial and withdrawal phase of discharge, while the entire estuary filled with freshwater with weak stratification during peak discharge period. Salt water intruded by 2-3 km further upstream during spring than neap tide resulting in $\sim 9 \%$ more saltier water during former than latter period. Modification in bathymetry of estuary during recent years enhanced salt content in the estuary and it may have significant impact on concentrations of nutrients and plankton biomass which may in turn influence food web structure. More integrated studies are required to examine how food web structure is changed in the Godavari estuary in recent years due to anthropogenic interventions.

\section{Acknowledgements}

Authors thank the Director, CSIR-NIO, Goa and Dr V S N Murty, the Scientist-in-Charge, CSIRNIO Regional Centre, Visakhapatnam for encouragement and support. They thank the team that collected the datasets during 2008-2009 and appreciate the help of boat personnel during sampling. This work is a part of the Council of Scientific and Industrial Research (CSIR) supported Supra Institutional Project (SIP-1308). Thanks to the reviewers for their valuable suggestions/comments which helped to improve the original version of the manuscript. This is NIO contribution number 5735.

\section{References}

Acharyya T 2012 Variability of phytoplankton pigment composition in a tropical monsoon driven estuary (Godavari, India): Natural and anthropogenic influences; PhD thesis, Andhra University, Visakhapatnam.

Acharyya T, Sarma V V S S, Sridevi B, Venkataramana V, Bharathi M D, Naidu S, Kumar B S K, V R Prasad, Bandopadhyay D, Reddy N P C and Kumar M D 2012 Reduced river discharge intensifies phytoplankton bloom in Godavari estuary, India; Mar. Chem. 132-133 15-22.

Bowden K F 1980 Chemistry and biogeochemistry of estuaries (eds) Olaussian E and Cato J, John Wiley \& Sons, New York.

Cameron W M and Pritchard D W 1963 Estuaries; In: The Sea (ed.) Hill M N (New York: John Wiley \& Sons) 2 306-324.

Dyer K R 1973 Estuaries: A Physical Introduction; 2nd edn, John Wiley \& Sons, London.

Hansen D V and Rattray M 1966 New dimensions in estuary classification; Limnol. Oceanogr. 11 319-326.

Haas L W 1977 The effect of the spring-neap tidal cycle on the vertical salinity structure of the James, York and Rappahannock rivers, Virginia, USA; Estuarine Coast. Shelf Sci. 5 485-496.

Huang W 2007 Hydrodynamic modeling of flushing time in a small estuary of North Bay, Florida, USA; Estuarine Coast. Shelf Sci. 74 722-731.

Jay D A and Smith J D 1990 Residual circulation in shallow estuaries 1. Highly stratified, Narrow estuaries; $J$. Geophys. Res. 95 711-731.

Jyothi D, Ramana Murty T V, Sarma V V and Rao D P 2000 Computation of diffusion coefficients for waters of Gauthami-Godavari estuary using one-dimensional advection-diffusion model; Indian J. Mar. Sci. 29 185187.

Luketina D 1998 Simple tidal prism models revisited; Estuarine Coast. Shelf Sci. 46 77-84.

Monsen N E, Cloren J E, Lucas L V and Monismith S G 2002 A comment on the use of flushing time, residence time and age as transport time scales; Limnol. Oceanogr. 47 1545-1553. 
Narasimha Rao T V 2001 Time-dependent stratification in the Gouthami-Godavari estuary; Estuaries 24 18-29.

Preethi B, Revadekar J V and Kripalani R H 2011 Anomalous behavior of the Indian summer monsoon 2009; J. Earth Syst. Sci. 120 783-794.

Pritchard D W 1952 Estuarine hydrography; In: Advances in Geophysics, Indian Acad. Press, New York, pp. 243-280.

Ralston A and Wilf H S 1966 Spline functions, interpolation and numerical quadrature in mathematical methods for digital computers (ed.) Greville T N E (New York: John Wiley), pp. 156-293.

Ranga Rao V, Ramana Y V and Reddy B S R 1988 Salinity \& current distribution in the Godavari estuary, east coast of India; Indian J. Mar. Sci. 17 14-18.

Ranga Rao V 1991 Some studies on the dynamics and physical features of the Godavari estuary, east coast of India; Ph.D thesis, Andhra University, Visakhapatnam.

Rao K L 1975 India's water wealth, its assessment, uses and projections; Orient Longman, New Delhi, 225p.

Reddy B S R and Ranga Rao V 1993 Flushing and dispersion characteristics of Godavari estuary under different river discharge conditions; Indian J. Mar. Sci. 2 111-114.
Sarma V V S S, Gupta S N M, Babu P V R, Acharya T, Harikrishnachari N, Vishnuvardhan K, Rao N S, Reddy N P C, Sarma V V, Sadhuram Y, Murty T V $\mathrm{R}$ and Kumar M D 2009 Influence of river discharge on plankton metabolic rates in the tropical monsoon driven Godavari estuary, India; Estuarine Coast. Shelf Sci. 85 $515-524$.

Sheldon J E and Alber Merryl 2006 The calculation of estuarine turnover times using freshwater fraction and tidal prism models: A critical evaluation; Estuar. Coasts 29 133-146.

Shetye S R, Michael G S and Chavan P V C 2007 Mixing and intrusion of salt; In: The Mandovi and Zuari Estuaries (eds) Shetye S R, Dileepkumar M and Shankar D (National Institute of Oceanography, India), pp. 49-58.

Sridevi B 2013 A comprehensive study on physical processes and their impact on biogeochemistry of Godavari estuary, India; PhD thesis, Andhra University, Visakhapatnam.

Vijith V, Sundar D and Shetye S R 2009 Time-dependence of salinity in monsoonal estuaries; Estuarine Coast. Shelf Sci. 85 601-608. 